九州大学学術情報リポジトリ

Kyushu University Institutional Repository

\title{
A Novel Phytoalexin Formed in Mulberry Leaves at the Infection of Phloeospora maculans, Causal Agent of Leaf Spot
}

Kim, Kyung-Hee

Laboratory of Plant Pathology, Faculty of Agriculture, Kyushu University

Matsuyama, Nobuaki

Laboratory of Plant Pathology, Faculty of Agriculture, Kyushu University

https://doi.org/10.5109/24254

出版情報: 九州大学大学院農学研究院紀要. 43 (1/2), pp. 89-93，1998-11. Kyushu University バージョン：

権利関係 : 


\title{
A Novel Phytoalexin Formed in Mulberry Leaves at the Infection of Phloeospora maculans, Causal Agent of Leaf Spot
}

\author{
Kyung-Hee Kim and Nobuaki Matsuyama \\ Laboratory of Plant Pathology, Faculty of Agriculture, \\ Kyushu Lniversity, Fukuoka 812-8581, Japan \\ (Received July 30, 1998 and accepted August 7, 1998)
}

\begin{abstract}
A novel terpenoid-type phytoalexin was isolated from mulberry leaves infected with Phloespora maculans, causal agent of leaf spot. The molecular formula and weight of this substance were decided as $\mathrm{C}_{2} \mathrm{H}_{2+} \mathrm{O}_{4}$ (MWt. 340) by $\mathrm{HR} /(+) \mathrm{FAB}$ mass spectrometry. This substance is detectable at Rf 0.56 on TLC chromatogram developed with chloroformmethanol $(9: 1, v / v)$ as a reddish-purple spot by spraying of $1 \%$ vanillin-sulfuric acid and heating at $110^{\circ} \mathrm{C}$. This substance appeared at Rt $13.6 \mathrm{~min}$ on the GLC chromatogram $\left(\mathrm{OV}-101,200^{\circ} \mathrm{C}\right.$, $\mathrm{N}_{2} 50 \mathrm{~mL} / \mathrm{min}$ ) and at Rt $4.5 \mathrm{~min}$ on HPLC chromatogram with reverseci-phase column (C18, $1 \mathrm{ml} / \mathrm{min}, 80 \%$ aqueous methanol). Other kind of substances which showed antifungal activity were also detected on the TIC chromatogram. These substances were absent in the extract from healthy check.
\end{abstract}

\section{INTRODUCTION}

The phytoalexin production at the site of infection has been well-documented since the first report of Müller and Börger in 1940. The close association of these phytoalexins with the defence to the parasites has also been indicated (Bailey et al., 1982).

The production of various kind of phytoalexins such as 26 kinds of Moracin (A Z), Oxyresveratrol, 4'-prenyloxyresveratrol and Chalcomoracin has been well noted (Shirata, 1978, 1981; Shirata et al., 1979, 1982a, 1982b; Takasugi et al., 1978a, 1978b, 1978c, 1979, 1980). The reason why the existence of such numerous kind of phytoalexins in mulberry plant has been attributed to the tissue-specific production of phytoalexin. Moracin M, however, was isolated from diseased epidermal tissues and xylem of twigs. Furthermore, Chalcomoracin was isolated not only from diseased leaf and also from diseased epidermal tissues and xylem of twigs (Takasugi et al., 1980).

Since 1991, mulberry plants in Goto islands (Nagasaki prefecture) have been severely attacked every year by Phloeospora maculans, causal agent of leaf spot (Negi et al., 1992) and silk-worm industry has been heavily depressed. According to our survey, there was a resistant variety to this pathogen. To examine if the phytoalexin will associate with the resistance, the extraction of phytoalexin in mulberry leaves was conducted.

The abstract was reported elsewhere (Kim et al., 1992) and the detail will be contributed in this report.

\section{MATERIALS AND METHODS}

\section{Extraction and purification of phytoalexin}

Twenty gram of diseased leaves of mulberry plant, cultivar "Minamisakari" was 
scissored and dipped in $200 \mathrm{ml}$ of $70 \%$ aqueous methanol. After keeping for $3 \mathrm{~min}$ in boiling water bath, the leaf sample was homogenized with the Physcotron homogenizer. The extract was concentrated to $\mathrm{ca}$. $50 \mathrm{ml}$ and shaked with twice volume of petroleum ether. The ether extract was concentrated completely and dissolved in $3 \mathrm{ml}$ of methanol.

The extract was applied on TLC plate of silica gel 60 (Merck Co.) and developed with chloroform-methanol $(9: 1, \mathrm{v} / \mathrm{v})$. The TLC plate was sprayed with $1 \%$ vanillin-sulfuric acid and heated at $110^{\circ} \mathrm{C}$ for detection of terpenoid-type phytoalexin. UV irradiation to TLC plate was also conducted to detect, other types of phytoalexin.

Preparative TLC was conducted and the corresponding area where phytoalexin-like substance was detected at preliminary tests was scraped. The silica-gel powder was suspended in chloroform-methanol $(2: 1, \mathrm{v} / \mathrm{v})$ and the substance was extracted. This sample was dissolved in $80 \%$ aqueous methanol and was subjected to HPLC with reversed-phase column (M\&S pack C18, 20×250 mm) and eluted with $80 \%$ aqueous methanol monitoring at $236 \mathrm{~nm}$.

\section{Analytical GLC and HPLC}

Analytical GLC and HPLC were conducted. GLC was performed by Shimadzu GLC 7AG equipped with FID and OV-101 column (1\% loading on Gas Chrom Q, 100/200 mesh in silanized glass column $0.3 \times 150 \mathrm{~cm}$ ). Analysis was conducted at $200^{\circ} \mathrm{C}$ and $50 \mathrm{ml} / \mathrm{min}$ $\mathrm{N}$. flow rate. HPLC was performed by Gilson 303 LC system equipped with the reversed-phase column (M\&S pack C18, $4.6 \times 150 \mathrm{~mm}$ ). Elution was carried out with $80 \%$ aqueous methanol at a flow rate of $1 \mathrm{ml} / \mathrm{min}$ monitoring at $236 \mathrm{rum}$.

\section{Mass spectrometry}

The purified substance was analyzed by a high resolution $\mathrm{HR} /(+) \mathrm{FAB}$ mass spectrometer at the Faculty of Pharmaceutical Sciences, Kyushu University.

\section{Antifungal activity}

Antifungal activity of the substances against $P$. maculans was tested by suspending spores which were formed on PSA medium in a drop of each sample solution on a glass slide keeping under humid condition.

\section{RESULTS AND DISCLSSION}

Extraction and characterization of phytoalexins formed in the leaves of mulberry by the infection with $P$. maculans were conducted. As can be seen in Fig. 1-1, bluish, purplish and reddish spots were detected on TLC plate at Rf $0.47,0.43$ and 0.33 when UV $(254 \mathrm{~nm})$ light was irradiated. These spots were not detected on the chromatogram of the healthy check leaves. At the visualization with $1 \%$ vanillin-sulfuric acid followed by heating at $110^{\circ} \mathrm{C}$, reddish-purple spot was observed at Rf 0.56 on the chromatogram of the infected leaves (Fig. 1-2).

Antifungal activity as phytoalexin was tested for eluates from corresponding areas at Rf $0.56,0.47,0.43$ and 0.33 , respectively. Every fraction showed antifungal activity and relatively strong inhibition was observed for the fractions from $\mathrm{Rf} 0.56,0.47$ and 0.33 . However, further analyses for these fractions with other kind of solvent-systems of TLC 

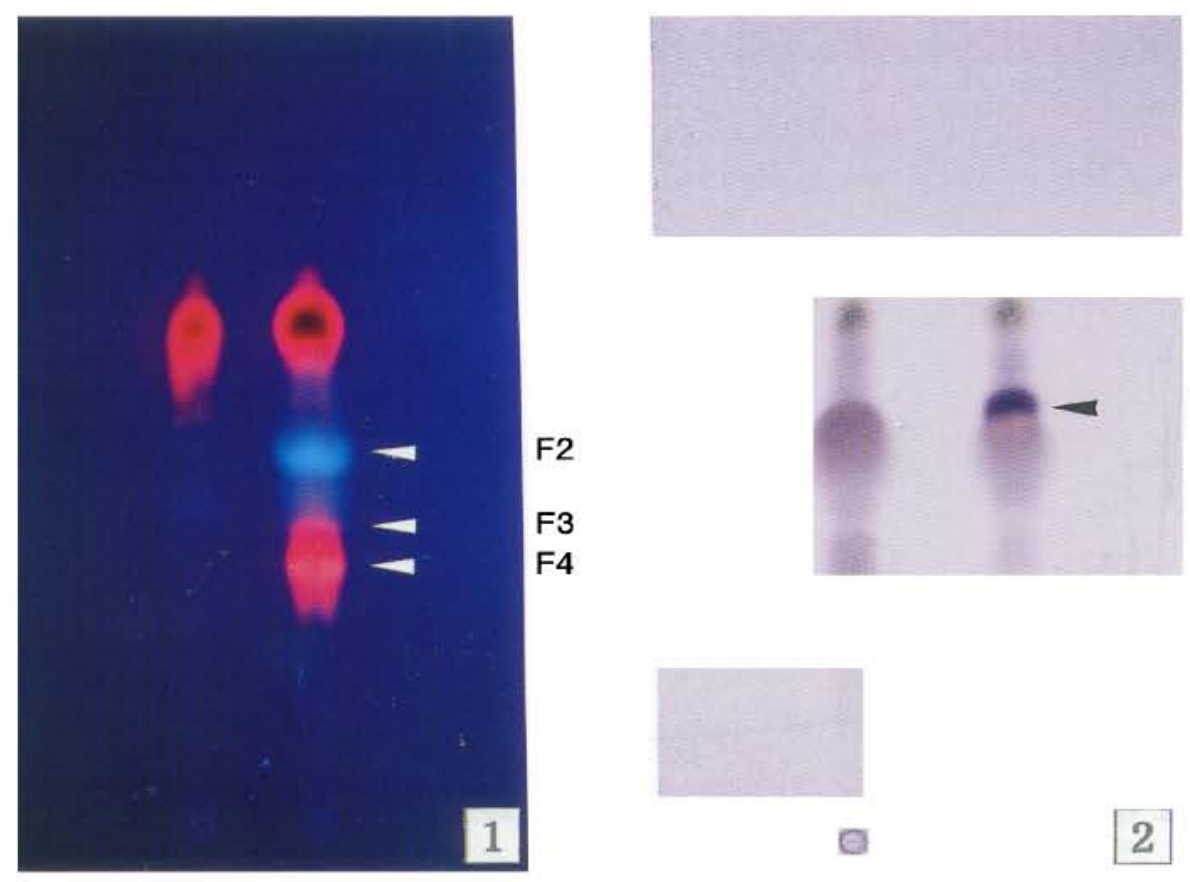

F2
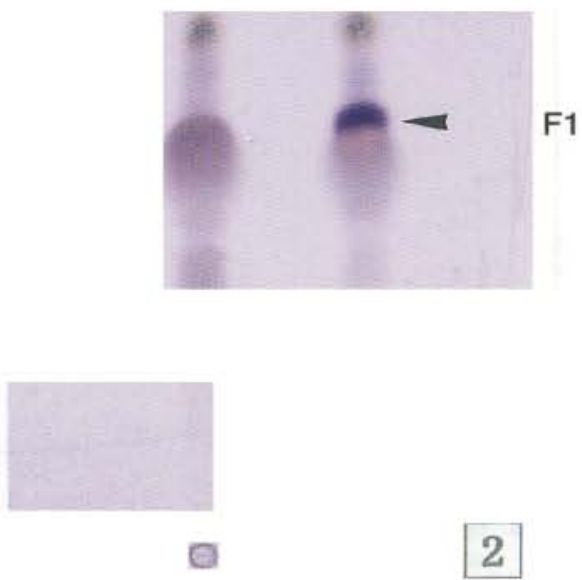

Fig. 1. TLC chromatograms of petroleum ether extracts from healthy (left of each figure) and infected leaves with $P$. maculans (right of each figure).

1. At UV irradiation $(254 \mathrm{~nm})$

2. At spraying $1 \%$ vanillin-sulfuric acid and heating

F1-F4: Fractions detected at Rf $0.56,0.47,0.43$ and 0.33

Solvent : chloroform-methanol $(9: 1, \mathrm{v} / \mathrm{v})$

Plate: Silica gel 60

such as ethyl acetate-carbon tetrachloride $(6: 4, \mathrm{v} / \mathrm{v})$ and cyclohexane-dioxane $(7: 3, \mathrm{v} / \mathrm{v})$ indicated that each fraction is a complex of weakly antifungal substances.

Only the substance at $\operatorname{Rf} 0.56$ which is detectable with $1 \%$ vanillin-sulfuric acid seemed to be single substance and showed strong antifungal activity. This substance was detected at Rt $13.6 \mathrm{~min}$ on GLC chromatogram with OV-101 column and appeared at Rt 4.5 min on HPLC chromatogram with reversed-phase column (Fig. 2). This fraction was subjected to preparative HPLC and the fraction at Rt $32.5 \mathrm{~min}$ was collected. After the tests for purity, the substance was subjected to a high resolution mass spectrometry $(\mathrm{HR} /(+) \mathrm{FABMS})$. The molecular formula and weight of this purified substance were decided as $\mathrm{C}_{31} \mathrm{H}_{3+} \mathrm{O}_{4}$ (MWt. 340) (Fig. 3). Since this substance was also detectable with $1 \%$ vanillin-sulfuric acid and $25 \%$ antimonate-chloroform, it was imagened that this novel substance will be a terpenoid-type phytoalexin. 


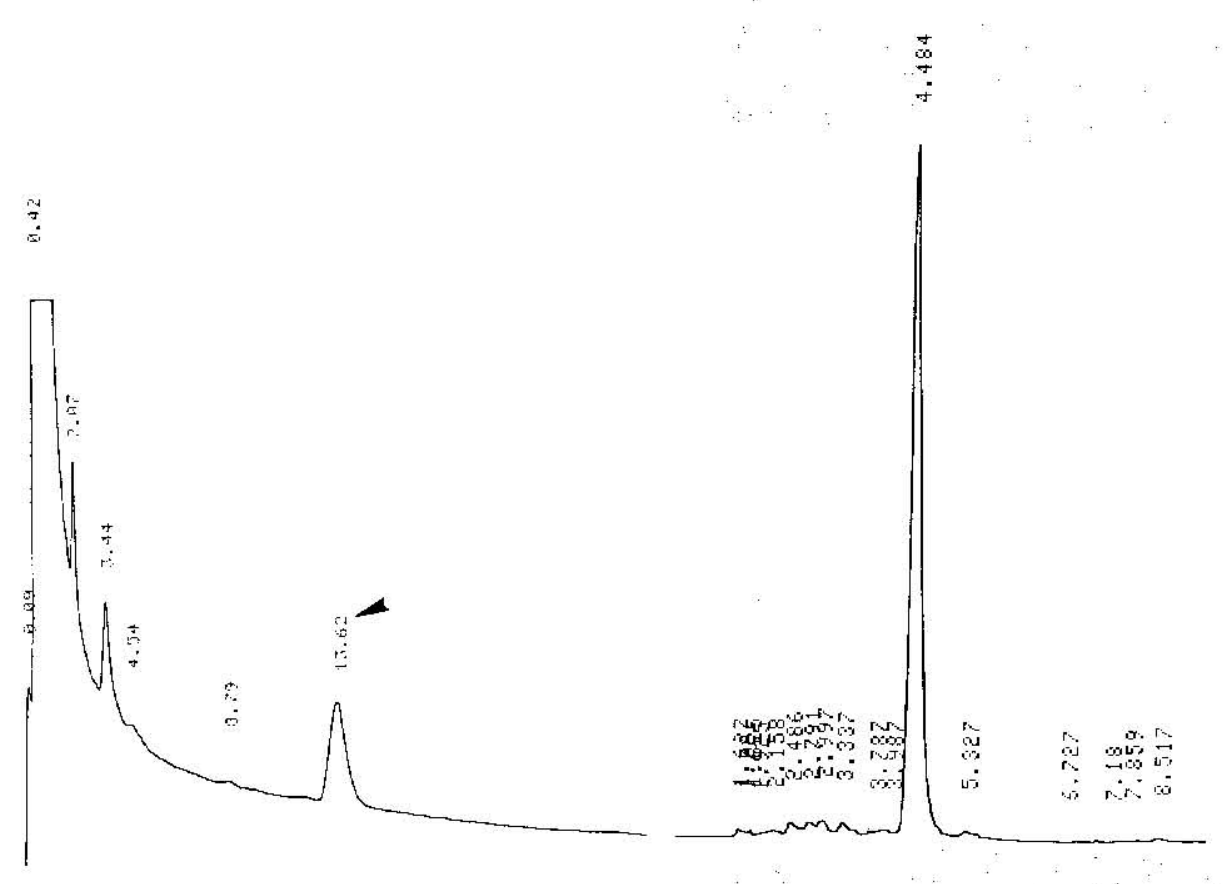

Fig. 2. Gas liquid ehromatography analysis (left) and high performance liquid churomalography analysis (right) of the substance at lal 0.56 . GLC: OV-101, $200^{\circ} \mathrm{C}$ column temperature, $\mathrm{N}_{-} 50 \mathrm{ml} / \mathrm{mirl}$ HPLC : Reversed-phase column C18, $1 \mathrm{ml} / \mathrm{min}, 80 \%$ aqueous methanol solution

\section{ACKNOWLEDGEMENT}

The authors are grateful to Dr. R. Isobe of the Faculty of Pharmaceutical Sciences, Kyushu University for his kind help at mass spectrometry. We are indebted to Mr. W. Negi, Mr. K. Ide and Dr. T. Ohta, staff of Nagasaki Prefecture for their kind help at collecting samples.

\section{REFERENCES}

Bailey, J. A. and J. W. Mansficld 1982 Pytoalcxins. Blackic, Glasgow \& London, 334pp.

Kim, K. H., N. Mat.snyama, T. Ota and W. Negi 1992 On the terpenoid-like substance produced in mulberry leaves diseased with the lcaf spot. Ann. Phytopathol. Soc. Jpn. 59(1): 51 (abstract, in Japanese)

Negi. W., K. Ide, T. Ota, N. Matsuyarna and K. H. Kim 1992 Severe occurrence of mulberry leaf spot in Goto, Nagasaki Prefecturc. Proc. Assoc. Pl. Prot. Kyushu 38: 52-54 (in Japanese)

Shirala, A. 1978 Production of phytoalexin in cortex tissue of mulberry shoot. Ann. Phytopathol. Soc. Jpn. 44: 485-492 (in Jajoarlese)

Shirala, A. 1981 Mechanisin of resistance in mulberry shoots to fungal diseases. Plant Protection. 35(11): 505-510 (in Japanese) 


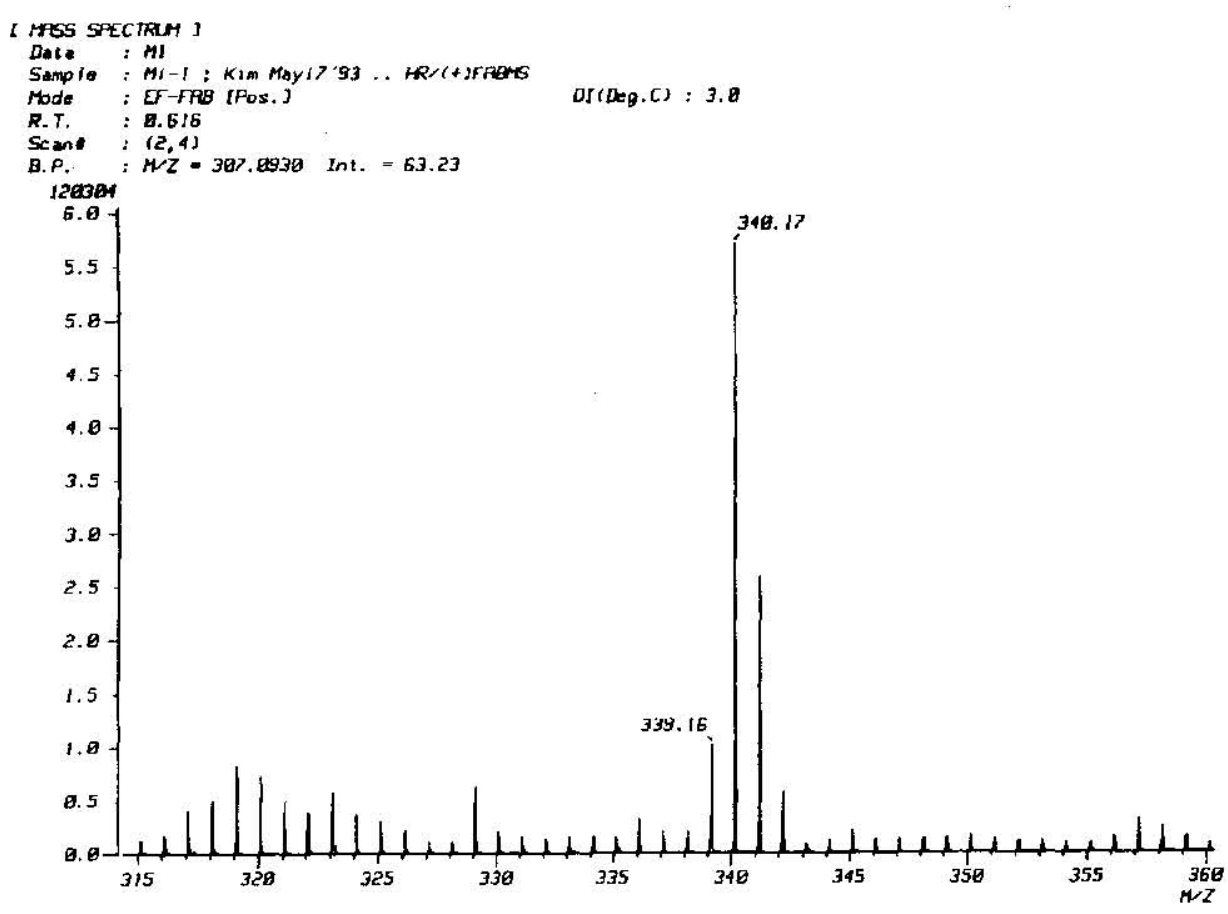

Fig. 3. $H R /(+) F A B$ mass spectrum of a novel phytoalexin.

Shirata, A. and K. Takahashi 1979 Production of phytoalexins in xylem tissue of mulberry shoot. Ann. Phytopathol. Soc. Jpn 45: 162-167 (in Japanese)

Shirata, A. and K. Takahashi $1982 \mathrm{a}$ Production of antifungal substances in the root of nulberry. Bull. Sericul. Exp. Sta. 28(5): 691-705 (in Japanese)

Shirata, A. and K. Takahashi 1982b Detection and production of antimicrobial substances in leaves of mulberry and other Moraceae tree planats. Bull. Sericul. Exp. Sta. 28(5): 707-718 (in Japanese)

Takasugi, M., S. Nagao and T. Masamune 1978a Structure of moracin A and B, new phytoalexins from diseased mulberry. Tetrahedron Letters 9: 797-798

Takasugi, M., L. Munoz, T. Masamune, A. Shirata, and K. Takahashi 1978b Stilbene phytoalexins from diseased mulberry. Chemistry Letters: 1241-1242

Takasugi, M., S. Nagao, and T. Masamune 1979 Sturactures of moracin E, F, G, and H, new phytoalexins from diseased mulberry. Tetrahedron Letters $\mathbf{4 8}: 4675-4678$

Takasugi, M., S. Nagao, T. Masamune, A. Shirata and K. Takahashi 1980 Chalcomoracin, a notural Diels-Alder adduct from mulberry. Chemistry Letters: $1573-1576$

Takasugi, M., S. Nagao, S. Lerı, T. Masamune, A. Shirata, and K. Takahashi $1978 \mathrm{c}$ Moracin C and D, new phytoalexins from diseased mulberry. Chemistry Letters: 1239-1240 